\title{
Mesorhizobium ciceri biovar biserrulae, a novel biovar nodulating the pasture legume Biserrula pelecinus L.
}

\author{
Kemanthi G. Nandasena, ${ }^{1}$ Graham W. O'Hara, ${ }^{1}$ Ravi P. Tiwari, ${ }^{1}$ \\ Anne Willlems ${ }^{2}$ and John G. Howieson ${ }^{1}$ \\ ${ }^{1}$ Centre for Rhizobium Studies, Murdoch University, Murdoch, Western Australia 6150, Australia \\ ${ }^{2}$ Laboratory of Microbiology, Faculty of Sciences, Ghent University, B-9000 Ghent, Belgium
}

Correspondence

Kemanthie Nandasena

K.Nandasena@murdoch.edu.au

\begin{abstract}
Biserrula pelecinus $L$. is a pasture legume species that forms a highly specific nitrogen-fixing symbiotic interaction with a group of bacteria that belong to Mesorhizobium. These mesorhizobia have $>98.8 \%$ sequence similarity to Mesorhizobium ciceri and Mesorhizobium loti for the $16 \mathrm{~S}$ rRNA gene (1440 bp) and $>99.3 \%$ sequence similarity to $M$. ciceri for the dnaK gene (300 bp), and strain WSM1271 has $100 \%$ sequence similarity to M. ciceri for GSII (600 bp). Strain WSM1271 had $85 \%$ relatedness to M. ciceri LMG $14989^{\top}$ and $50 \%$ relatedness to M. loti LMG $6125^{\top}$ when DNA-DNA hybridization was performed. WSM1271 also had a similar cellular fatty acid profile to $M$. ciceri. These results are strong evidence that the Biserrula mesorhizobia and $M$. ciceri belong to the same group of bacteria. Significant differences were revealed between the Biserrula mesorhizobia and $M$. ciceri in growth conditions, antibiotic resistance and carbon source utilization. The $\mathrm{G}+\mathrm{C}$ content of the DNA of WSM1271 was $62.7 \mathrm{~mol} \%$, compared to 63-64 mol\% for M. ciceri. The Biserrula mesorhizobia contained a plasmid ( $\sim 500 \mathrm{bp})$, but the symbiotic genes were detected on a mobile symbiosis island and considerable variation was present in the symbiotic genes of Biserrula mesorhizobia and $M$. ciceri. There was $<78.6 \%$ sequence similarity for nod $A$ and $<66.9 \%$ for $n i f H$ between Biserrula mesorhizobia and $M$. ciceri. Moreover, the Biserrula mesorhizobia did not nodulate the legume host of M. ciceri, Cicer arietinum, and $M$. ciceri did not nodulate $B$. pelecinus. These significant differences observed between Biserrula mesorhizobia and M. ciceri warrant the proposal of a novel biovar for Biserrula mesorhizobia within M. ciceri. The name Mesorhizobium ciceri biovar biserrulae is proposed, with strain WSM1271 (=LMG $23838=$ HAMBI 2942) as the reference strain.
\end{abstract}

Biserrula pelecinus L. is an annual herbaceous legume suited to arid land, which is rapidly gaining popularity as a forage species in Australia (Howieson et al., 1995, 2000; Loi et al., 2005). The Mediterranean basin is the centre of origin of this monospecific genus (Allen \& Allen, 1981). B. pelecinus forms a highly specific nitrogen-fixing symbiotic association with bacteria that have been classified within the genus Mesorhizobium (Howieson et al., 1995; Nandasena et al., 2001, 2004).

Four strains (WSM1271, WSM1283, WSM1284 and WSM1497) isolated from B. pelecinus growing in the Mediterranean basin shared $>98.8 \%$ sequence similarity to Mesorhizobium ciceri and Mesorhizobium loti for the $16 \mathrm{~S}$

\footnotetext{
The GenBank/EMBL/DDBJ accession numbers for the dnaK gene sequences of the Biserrula mesorhizobia are EF035140-EF035149 and DQ485740-DQ485743, and those for the GSII gene sequences of the Biserrula mesorhizobia are EF035150-EF035159 and DQ485748-DQ485751.
}

rRNA gene (1440 bp) (Nandasena et al., 2001; K. G. Nandasena, G. W. O'Hara, R. P. Tiwari and J. G. Howieson, unpublished results). To investigate whether phylogenetically diverse strains nodulate $B$. pelecinus growing in its centre of origin, we sequenced variable regions of two housekeeping genes, dnaK and GSII, for these four strains and for another ten strains isolated from B. pelecinus growing in undisturbed locations within the Mediterranean basin, including Morocco, several Greek islands in the Cyclades group and several different sites on Sardinia (Table 1).

The locus dnaK encodes a highly conserved chaperone protein with multiple cellular functions, and this gene has proven to be a useful diagnostic tool for root-nodule bacteria (Stepkowski et al., 2003; Eardly et al., 2005). A $300 \mathrm{bp}$ intragenic fragment from the variable region of $d n a K$ was amplified and sequenced using the primers TSdnaK2 and TSdnaK3 (Stepkowski et al., 2003). Ten strains, WSM1283, WSM1448, WSM1449, WSM1493, WSM1497, 
Table 1. Collection details of Biserrula mesorhizobia from the Mediterranean basin

\begin{tabular}{|c|c|c|c|c|c|c|c|c|}
\hline Strain & Location & $\begin{array}{l}\text { Altitude } \\
\quad(\mathbf{m})\end{array}$ & $\begin{array}{l}\text { Rainfall } \\
(\mathbf{m m})\end{array}$ & Soil type & $\begin{array}{l}\text { Soil } \\
\text { pH }\end{array}$ & Habitat & Grazing & Collector(s) \\
\hline WSM1271 & Bottida, Sardinia & 295 & - & Sandy loam & 5.5 & Fallow & Heavy & J. G. Howieson \\
\hline WSM1283 & Oulmes, Morocco & 1100 & 600 & Sand & 6 & Pasture & Heavy & J. G. Howieson \\
\hline WSM1284 & Siniscola, Sardinia & 30 & - & Sand & 6.2 & Grassland & Light & J. G. Howieson \\
\hline WSM1448 & Falatados, Greece & 300 & 600 & Loamy sand & 7 & Pasture & Light & S. Carr and B. Nutt \\
\hline WSM1449 & Frantato, Greece & 150 & 600 & Sand & 7 & Fallow & Nil & S. Carr and B. Nutt \\
\hline WSM1450 & Frantato, Greece & 150 & 600 & Sand & 7 & Fallow & Nil & S. Carr and B. Nutt \\
\hline WSM1493 & Ios, Greece & 0 & 350 & Sandy loam & 7 & Pasture & Light & S. Carr and B. Nutt \\
\hline WSM1497 & Mykonos, Greece & 30 & 450 & Sandy loam & 8 & Pasture & Light & S. Carr and B. Nutt \\
\hline WSM1533 & $\begin{array}{l}\text { Aggius-Luogosanto, } \\
\text { Sardinia }\end{array}$ & 300 & 850 & Sand & $5.5 / 6.0$ & Pasture & Heavy & A. Loi, S. Carr and C. Porqueddu \\
\hline WSM1539 & $\begin{array}{l}\text { Cagliari-Muravera, } \\
\text { Sardinia }\end{array}$ & 345 & - & Sandy loam & 7 & Pasture & Heavy & A. Loi, S. Carr and C. Porqueddu \\
\hline WSM1540 & $\begin{array}{l}\text { Cagliari-Muravera, } \\
\text { Sardinia }\end{array}$ & 345 & - & Sandy loam & 7 & Pasture & Heavy & A. Loi, S. Carr and C. Porqueddu \\
\hline WSM1548 & $\begin{array}{l}\text { Pattada-Bentutti, } \\
\text { Sardinia }\end{array}$ & 265 & 750 & Sandy loam & 6 & Pasture & Heavy & A. Loi, S. Carr and C. Porqueddu \\
\hline WSM1562 & Quarta, Sardinia & 50 & - & Sandy loam & 7 & Pasture & Light & A. Loi, S. Carr and C. Porqueddu \\
\hline WSM1568 & Ozieri, Sardinia & 430 & 650 & Sandy loam & $5.5 / 6.0$ & Pasture & Light & A. Loi, S. Carr and C. Porqueddu \\
\hline
\end{tabular}

- , No information available.

WSM1533, WSM1539, WSM1548, WSM1562 and WSM1568, had identical partial dnaK sequences, while the other four strains (WSM1271, WSM1284, WSM1450 and WSM1540) differed by only 1 or $2 \mathrm{bp}$. These Biserrula mesorhizobia had $>99.3 \%$ sequence similarity to M. ciceri and $<91.9 \%$ sequence similarity to $M$. loti and, as a consequence, all 14 Biserrula mesorhizobia given in Table 1 clustered with $M$. ciceri when a phylogenetic tree was developed (not shown) using the available partial dnaK sequences of type strains of root-nodule bacteria.

Sequences for two glutamine synthetases (GSI and GSII) have been used to determine genetic relationships among root-nodule bacteria (Turner \& Young, 2000). To provide further evidence for the grouping of the Biserrula mesorhizobia and M. loti, a $600 \mathrm{bp}$ intragenic fragment of a glutamine synthetase gene (GSII) was amplified and sequenced using the primers GSII-1 and GSII-2 (Turner \& Young, 2000). Eight of the strains, WSM1283, WSM1284, WSM1448, WSM1450, WSM1533, WSM1539, WSM1540 and WSM1548, shared identical sequences for GSII, and these sequences gave $100 \%$ sequence similarity to M. ciceri, while they were only $90.4 \%$ similar to $M$. loti. The other six Biserrula mesorhizobia, WSM1271, WSM1449, WSM1493, WSM1497, WSM1562 and WSM1568, had 1 or 2 bp differences from the GSII sequence of the first eight strains. All 14 Biserrula mesorhizobia given in Table 1 clustered together with $M$. ciceri when a phylogenetic tree was developed (not shown) using the GSII sequences of available type strains of 21 root-nodule bacteria, thereby confirming the phylogenetic relationships developed with the 16S rRNA gene and dnaK.
The similarities observed for 16S rRNA, dnaK and GSII genes are strong evidence that $B$. pelecinus growing in its centre of origin is nodulated by a very similar group of bacteria currently classified within the rhizobial species $M$. ciceri. At present, 11 species of Mesorhizobium have been proposed, ten of which, Mesorhizobium amorphae, $M$. chacoense, M. ciceri, M. huakuii, M. loti, M. mediterraneum, M. plurifarium, M. septentrionale, M. temperatum and $M$. tianshanense, have been shown to form nitrogen-fixing symbiotic associations with leguminous plants (Gao et al., 2004; Chen et al., 2005; Ghosh \& Roy, 2006). All ten species share $>97.7 \%$ sequence similarity for the 16S rRNA gene and it is recommended that DNA-DNA hybridization values be included when describing novel species within this genus (Chen et al., 2005). Therefore, DNA-DNA hybridization was performed [microplate method described by Ezaki et al. (1989) as modified by Goris et al. (1998)] between Biserrula mesorhizobium strain WSM1271 and the type strain of M. ciceri LMG $14989^{\mathrm{T}}$. A relatedness value of $85 \%$ between the two strains was obtained, providing evidence that they can be regarded as members of the same bacterial species. DNA-DNA hybridization values between Biserrula mesorhizobium strain WSM1271 and the type strain of $M$. loti LMG $6125^{\mathrm{T}}$ were $50 \%$.

Cellular fatty acid analysis provides a useful tool in identification of root-nodule bacteria (Tighe et al., 2000). Therefore, cellular fatty acid analysis was undertaken for strains WSM1271 and WSM1497 as described by Tighe et al. (2000). The fatty acids of WSM1271 and WSM1497 were straight-chain saturated fatty acids, unsaturated fatty acids, 11-methyl-branched unsaturated fatty acids and 3-hydroxy 
fatty acids. Although the fatty acid patterns of these two strains were diagnostic of root-nodule bacteria in general, the strains could not be assigned to any of the published root-nodule bacterial species when the fatty acid patterns were compared with all the bacterial strains available in the MIS fatty acid database (MIDI Inc.). However, similar fatty acid profiles were observed for $M$. ciceri and the two strains of Biserrula mesorhizobia for the fatty acids that were present in amounts $>0.25 \%$ (Table 2). This observation further confirms that the Biserrula mesorhizobia are members of M. ciceri.

However, there are significant variations between the Biserrula mesorhizobia and $M$. ciceri for a number of phenotypic and symbiotic characteristics. As we have concluded that $B$. pelecinus is being nodulated by a very similar group of phylogenetically related bacteria, further descriptions and comparisons of Biserrula mesorhizobia were based on the initial four strains (WSM1271, WSM1283, WSM1284 and WSM1497). Biserrula mesorhizobia cannot grow at $2 \%(\mathrm{w} / \mathrm{v}) \mathrm{NaCl}$ (Nandasena et al., 2001), while M. ciceri can (Jarvis et al., 1997). M. ciceri is resistant to chloramphenicol (Nour et al., 1994), while the Biserrula mesorhizobia are sensitive to this antibiotic (K. G.

Table 2. Fatty acid compositions (\%) of $M$. ciceri and Biserrula mesorhizobium strains WSM1497 and WSM1271

Data for $M$. ciceri are mean contents for nine strains taken from Tighe et al. (2000).

\begin{tabular}{|lccc|}
\hline Fatty acid & WSM1497 & WSM1271 & M. ciceri \\
\hline $12: 0$ 3-OH & 0.37 & 0.53 & 0.27 \\
$13: 0$ iso 3-OH & 0.42 & 0.45 & 0.24 \\
Unknown (ECL 14.780) & & & 0.16 \\
$15: 0$ iso & & & 0.18 \\
$15: 0$ & & & 0.02 \\
$16: 0$ & 10.92 & 12.56 & 13.41 \\
$17: 0$ iso & 5.13 & 4.18 & 4.16 \\
$17: 1 \omega 8 c$ & 0.45 & 0.62 & 0.15 \\
$17: 0$ cyclo & 0.86 & 0.58 & 0.84 \\
$17: 0$ & 1.59 & 2.14 & 1.29 \\
Unknown (ECL 17.875) & & & 0.17 \\
$18: 0$ & 2.84 & 2.65 & 3.25 \\
11 -methyl 18:1 $\omega 7 c$ & 12.55 & 15.52 & 11.92 \\
$18: 1 \omega 9$ cis & & & 0.12 \\
Unknown (ECL 18.794) & & & 0.21 \\
$19: 0$ cyclo $\omega 8 c$ & 41.52 & 35.29 & 37.27 \\
10 -methyl 19:0 & 0.5 & 0.81 & 0.18 \\
$20: 0$ & & & 0.05 \\
$20: 1 \omega 9 t$ & & & 0.14 \\
$20: 2 \omega 6,9 c$ & 0.72 & 0.87 & 0.95 \\
Summed feature $4^{*}$ & & & 0.34 \\
Summed feature $7 *$ & 22.13 & 23.78 & 24.69 \\
& & & \\
\hline
\end{tabular}

${ }^{*}$ Summed feature 4 contains $15: 0$ iso $2-\mathrm{OH}$ and/or $16: 1 \omega 7 c$. Summed feature 7 contains $18: 1 \omega 7 c / \omega 9 t / \omega 12 t$.
Nandasena, G. W. O'Hara, R. P. Tiwari and J. G. Howieson, unpublished results). When compared with M. ciceri, Biserrula mesorhizobia are able to utilize a wider range of carbon sources (as the sole source of carbon). These include erythritol, L-xylose, adonitol, methyl $\beta$-xyloside, galactose, sorbitol, aesculin, cellobiose, melibiose, $\beta$-gentiobiose, $\mathrm{D}$ lyxose, D-tagatose and D-fucose [API 50CH and API 50CHE/ $\mathrm{B}$ medium (bioMérieux) were used to determine carbohydrate utilization profiles]. The $\mathrm{G}+\mathrm{C}$ content of the DNA of WSM1271 is $62.7 \mathrm{~mol} \%$, while this value is between 63 and $64 \mathrm{~mol} \%$ for M. ciceri.

The symbiotic genes of Biserrula mesorhizobia are located on a mobile symbiosis island and integrate into a phenylalanine tRNA gene (Nandasena et al., 2006), while such an element is not reported for M. ciceri. Furthermore, the symbiosis island of the Biserrula mesorhizobia contains a gene that encodes a phage P4-like integrase (intS) that is responsible for the excision and insertion of symbiosis islands (Nandasena et al., 2006). To investigate whether $M$. ciceri had a similar intS adjacent to a phenylalanine tRNA gene, we performed PCR with primers phetRNAf and intS522r (Nandasena et al., 2006). M. ciceri failed to give an amplification product, while $M$. loti and $M$. tianshanense produced an expected $800 \mathrm{bp}$ PCR product (data not shown). This indicates that M. ciceri may not have an intS adjacent to a phenylalanine tRNA as found in the Biserrula mesorhizobia.

The nodulation gene nodA determines the type of $\mathrm{N}$-acyl substitution transferred onto the oligosaccharide backbone of Nod factor and thus plays a significant role in determining the symbiotic specificity of root-nodule bacteria (Downie, 1998). A 567 bp intragenic fragment of nodA was sequenced for Biserrula mesorhizobial strains WSM1271, WSM1283, WSM1284 and WSM1497 (Nandasena et al., 2006), and there was $<78.6 \%$ sequence similarity between the nodA sequences of Biserrula mesorhizobia and that of the type strain of $M$. ciceri. Nitrogenase is the key enzyme in nitrogen fixation, and nifH is responsible for the structural development of component II of nitrogenase (Rubio \& Ludden, 2000). A 710 bp intragenic fragment of nifH was sequenced for Biserrula mesorhizobia strains WSM1271, WSM1283, WSM1284 and WSM1497 (Nandasena et al., 2006), and there was $<66.9 \%$ sequence similarity between the nifH sequences of Biserrula mesorhizobia and that of the type strain of M. ciceri. All Biserrula mesorhizobia clustered separately from all other species of Mesorhizobium when phylogenetic trees were developed separately for nodA and nifH sequences (Nandasena et al., 2006). Furthermore, M. ciceri is considered a monospecific cross-nodulation system, as it is unable to nodulate 88 plant species belonging to the Fabaceae and Mimosaceae and only nodulates chickpea (Cicer arietinum) (Gaur \& Sen, 1979). Our previous work has shown that $M$. ciceri is unable to nodulate B. pelecinus and Biserrula mesorhizobia are unable to induce nodules on Cicer arietinum (Nandasena et al., 2004), indicating that there is no cross-nodulation compatibility 
between M. ciceri and the Biserrula mesorhizobia. These results strongly indicate that the symbiotic genes of $M$. ciceri and the Biserrula mesorhizobia are significantly different. The considerable differences observed for phenotypic and symbiotic characteristics between M. ciceri and the Biserrula mesorhizobia warrant the Biserrula mesorhizobia to be regarded as a novel biovar, for which we propose the name M. ciceri biovar biserrulae.

\section{Description of Mesorhizobium ciceri biovar biserrulae}

Mesorhizobium ciceri biovar biserrulae is named after the legume host, Biserrula pelecinus L., with which these bacteria form a nitrogen-fixing symbiotic relationship.

Gram-negative rods $(0.5 \times 1 \mu \mathrm{m})$ with a polar or subpolar flagellum and containing granules of poly- $\beta$-hydroxybutyrate. They are moderately fast-growing, forming $2-4 \mathrm{~mm}$ diameter colonies within 4-5 days on YMA, and have a mean generation time of 4-6 h when grown in YMB at $28^{\circ} \mathrm{C}$. Colonies on YMA are white-opaque, slightly domed, moderately mucoid with smooth margins. Strains grow on YMA containing $1.5 \%(\mathrm{w} / \mathrm{v}) \mathrm{NaCl}$, but not with $2.0 \%(\mathrm{w} / \mathrm{v})$ $\mathrm{NaCl}$, and are able to tolerate a $\mathrm{pH}$ range between 5.5 and 8.0. Utilizes the following compounds as sole sources of carbon: glycerol, erythritol, D-arabinose, L-arabinose, ribose, D-xylose, L-xylose, adonitol, methyl $\beta$-xyloside, galactose, D-glucose, D-fructose, D-mannose, rhamnose, dulcitol, inositol, mannitol, sorbitol, aesculin, cellobiose, melibiose, $\beta$-gentiobiose, D-turanose, $\mathrm{D}$-lyxose, D-tagatose, D-fucose, L-fucose, D-arabitol and L-arabitol. Cannot utilize the following compounds as sole sources of carbon: methyl $\alpha$-D-mannoside, methyl $\alpha$-D-glucoside, amygdalin, inulin, melezitose, glycogen, xylitol, gluconate, 2-ketogluconate and 5-ketogluconate. Strains are sensitive to $\left(\mu \mathrm{g} \mathrm{ml}^{-1}\right)$ ampicillin (50), chloramphenicol (40), spectinomycin (50) and tetracycline (20) while they are resistant to gentamicin (40), kanamycin (50), nalidixic acid (50) and streptomycin (100). Synthesizes the following fatty acids: $12: 03-\mathrm{OH}$ (0.53\%), $13: 0$ iso $3-\mathrm{OH}(0.45 \%), 16: 0$ (12.56\%), $17: 0$ iso $(4.18 \%), 17: 1 \omega 8 c(0.62 \%), 17: 0$ cyclo $(0.58 \%), 17: 0$ (2.14\%), $18: 0$ (2.65\%), 11-methyl $18: 1 \omega 7 c(15.52 \%)$, $19: 0$ cyclo $\omega 8 c(35.29 \%), 10$-methyl 19:0 (0.81\%), $20: 2$ $\omega 6,9 c(0.87 \%)$ and summed feature $7(18: 1 \omega 7 c / \omega 9 t / \omega 12 t)$ $(23.78 \%)$. The $\mathrm{G}+\mathrm{C}$ content of the DNA is $62.7 \mathrm{~mol} \%$. Contains a single plasmid $(\sim 500 \mathrm{~kb})$. Symbiotic genes of this organism are located on a mobile symbiosis island and it is able to nodulate B. pelecinus and Astragalus membranaceus, while strains do not nodulate Cicer arietinum (Nandasena et al., 2004).

The reference strain is WSM1271 $(=$ LMG $23838=$ HAMBI 2942).

\section{Acknowledgements}

This work was supported by a post-doctoral research fellowship provided to the senior author by the Grains Research and Development
Corporation (GRDC) and Australian Wool Innovation Ltd (AWI) within the National Rhizobium Program. We thank the DSMZ, Germany, for helping in the analysis of cellular fatty acids of our strains.

\section{References}

Allen, O. N. \& Allen, E. K. (1981). The Leguminosae: a Source Book of Characteristics, Uses and Nodulation. London: Macmillan.

Chen, W. X., Wang, E. T. \& Kuykendall, L. D. (2005). Genus VI. Mesorhizobium Jarvis, van Berkum, Chen, Nour, Fernandez, CleyetMarel and Gillis 1997, 897 ${ }^{\mathrm{VP}}$. In Bergey's Manual of Systematic Bacteriology, 2nd edn, vol. 2, part C, pp. 403-408. Edited by D. J. Brenner, N. R. Krieg, J. T. Staley \& G. M. Garrity. New York: Springer.

Downie, J. A. (1998). Functions of rhizobial nodulation genes. In The Rhizobiaceae, pp. 387-402. Edited by H. P. Spaink, A. Kondorosi \& P. J. J. Hooykaas. Dordrecht: Kluwer Academic.

Eardly, B. D., Nour, S. M., van Berkum, P. \& Selander, R. K. (2005). Rhizobial 16S rRNA and $d n a K$ genes: mosaicism and the uncertain phylogenetic placement of Rhizobium galegae. Appl Environ Microbiol 71, 1328-1335.

Ezaki, T., Hashimoto, Y. \& Yabuuchi, E. (1989). Fluorometric deoxyribonucleic acid-deoxyribonucleic acid hybridization in microdilution wells as an alternative to membrane filter hybridization in which radioisotopes are used to determine genetic relatedness among bacterial strains. Int J Syst Bacteriol 39, 224-229.

Gao, J. L., Turner, S. L., Kan, F. L., Wang, E. T., Tan, Z. Y., Qiu, Y. H., Gu, J., Terefework, Z., Young, J. P. W. \& other authors (2004). Mesorhizobium septentrionale sp. nov. and Mesorhizobium temperatum sp. nov., isolated from Astragalus adsurgens growing in the northern regions of China. Int J Syst Evol Microbiol 54, 2003-2012.

Gaur, Y. D. \& Sen, A. N. (1979). Cross inoculation group specificity in Cicer-Rhizobium symbiosis. New Phytol 83, 745-754.

Ghosh, W. \& Roy, P. (2006). Mesorhizobium thiogangeticum sp. nov., a novel sulfur-oxidizing chemolithoautotroph from rhizosphere soil of an Indian tropical leguminous plant. Int J Syst Evol Microbiol 56, 91-97.

Goris, J., Suzuki, K., De Vos, P., Nakase, T. \& Kersters, K. (1998). Evaluation of a microplate DNA-DNA hybridization method compared with the initial renaturation method. Can J Microbiol 44, 1148-1153.

Howieson, J. G., Loi, A. \& Carr, S. J. (1995). Biserrula pelecinus L. - a legume pasture species with potential for acid, duplex soils which is nodulated by unique root-nodule bacteria. Aust J Agric Res 46, 997-1009.

Howieson, J. G., O'Hara, G. W. \& Carr, S. J. (2000). Changing roles for legumes in Mediterranean agriculture: developments from an Australian perspective. Field Crop Res 65, 107-122.

Jarvis, B. D. W., van Berkum, P., Chen, W. X., Nour, S. M., Fernandez, M. P., Cleyet-Marel, J. C. \& Gillis, M. (1997). Transfer of Rhizobium loti, Rhizobium huakuii, Rhizobium ciceri, Rhizobium mediterraneum, and Rhizobium tianshanense to Mesorhizobium gen. nov. Int J Syst Bacteriol 47, 895-898.

Loi, A., Howieson, J. G., Nutt, B. J. \& Carr, S. J. (2005). A second generation of annual pasture legumes and their potential for inclusion in Mediterranean-type farming systems. Aust J Exp Agric 45, 289-299.

Nandasena, K. G., O'Hara, G. W., Tiwari, R. P., Yates, R. J. \& Howieson, J. G. (2001). Phylogenetic relationships of three bacterial strains isolated from the pasture legume Biserrula pelecinus L. Int J Syst Evol Microbiol 51, 1983-1986.

Nandasena, K. G., O'Hara, G. W., Tiwari, R. P., Yates, R. J., Kishinevsky, B. D. \& Howieson, J. G. (2004). Symbiotic relationships 
and root nodule ultrastructure of the pasture legume Biserrula pelecinus L.; a new legume in agriculture. Soil Biol Biochem 36, 1309-1317.

Nandasena, K. G., O'Hara, G. W., Tiwari, R. P. \& Howieson, J. (2006). Rapid in situ evolution of nodulating strains for Biserrula pelecinus $\mathrm{L}$. through lateral transfer of a symbiosis island from the original mesorhizobial inoculant. Appl Environ Microbiol 72, 7365-7367.

Nour, S. M., Cleyet-Marel, J. C., Beck, D., Effosse, A. \& Fernandez, M. P. (1994). Genotypic and phenotypic diversity of Rhizobium isolated from chickpea (Cicer arietinum L.). Can J Microbiol 40, 345-354.

Rubio, L. M. \& Ludden, P. W. (2000). The gene products of the nif regulon. In Nitrogen Fixation at the Millennium, pp. 101-130. Edited by G. J. Leigh. Amsterdam: Elsevier.
Stepkowski, T., Czaplinska, M., Miedzinska, K. \& Moulin, L. (2003). The variable part of the $d n a K$ gene as an alternative marker for phylogenetic studies of rhizobia and related alpha Proteobacteria. Syst Appl Microbiol 26, 483-494.

Tighe, S. W., de Lajudie, P., Dipietro, K., Lindström, K., Nick, G. \& Jarvis, B. D. W. (2000). Analysis of cellular fatty acids and phenotypic relationships of Agrobacterium, Bradyrhizobium, Mesorhizobium, Rhizobium and Sinorhizobium species using the Sherlock Microbial Identification System. Int J Syst Evol Microbiol 50, 787-801.

Turner, S. L. \& Young, J. P. W. (2000). The glutamine synthetases of rhizobia: phylogenetics and evolutionary implications. Mol Biol Evol 17, 309-319. 